\title{
Report from Guiana
}

\section{N. O. Poonai}

First described by Sir Walter Raleigh, the region of Guiana comprises that part of northern South America lying between the Amazon and the Orinoco Rivers and their tributaries, the Rio Negro and the Casiquiare, and the Atlantic Ocean. Politically it forms part of the territories of Brazil and Venezuela, and includes Guyana, Suriname and Cayenne. It is entirely tropical, with mangrove swamps and forests, herbaceous swamps, wet and semi-arid savannas, swamp and seasonal forest and various types of rain forest. The vegetation is not uniform: there are clumps of forest in the swamps and savannas, and patches of coarse grasslands in the great forests.

Geologically this region, referred to as the Guyana Shield, has a central core of very ancient rocks, exposed in parts sometimes as rugged peaks and hills, but with much of the surface covered by a mantle of younger rocks; there are extensive surfaces of sand and laterite and near the ocean are deep clay deposits. The continental shelf is wide and muddy, and fairly uniform.

Settlement is confined to the coastlands and along the rivers where people engage mainly in agriculture. In the thinly settled hinterland people working mainly in lumbering, mining, herding and collecting; bauxite is mined in all the political units, and in Brazil and Venezuela manganese and iron are worked. On the savannas of the Rio Branco and the Llanos sparse herds of cattle graze the poor vegetation of the impoverished soils.

\section{New Conditions}

But conditions are changing rapidly across the entire region: forests are being cleared for settlement, roads cut across what has for centuries been considered impenetrable forest, new and extensive mines opened up in Amazonia and the lower Orinoco, and great artificial lakes created in Suriname, flooding out and killing many hundred square miles of dense forest. New modes of travel and transport help to open up remote wilderness lands, and the Amerindian is today no longer a neutral factor in the hinterland; guns have reached him and effective traps and nets are available for him to capture wild animals for the ruthless dealers and exporters.

As a result most states have been obliged to introduce stern and comprehensive laws restricting hunting and collecting of wild animals-Brazil's new game laws are some of the strictest in the world. Guyana is the only state in the region that has not introduced a conservation code, but laws would be difficult to enforce in a region so wide and remote, and legislation would have little effect on the habitat destruction and industrial expansion that must go on as population increases. The present is therefore a useful point at which to survey the wildlife of the region for future reference and comparison. 


\section{Status of Species}

Two species have not been reported in the region within recent years:

Horned Screamer Anhima cornuta-there is a bare possibility that it still survives in the Orinoco-Amacura delta.

Roseate spoonbill Ajaja ajaja-occasional visitors are sometimes seen on mudflats.

The following species are rare and may be considered threatened:

Giant anteater Myrmecophaga tridactyla

Giant armadillo Priodontes giganteus

Bush dog Speothos venaticus

Giant otter Pteronura brasiliensis

Manatee Trichechus manatus

Orinoco river turtle Podocnemis expansa

Black caiman Melanosuchus niger

Agami heron Agamia agami

Capped heron Philherodius pileatus

Orinoco goose Neochen jubata

The following will be threatened if present pressure continues:

Howler monkey Alouatta seniculus

Puma or cougar Felis concolor

Little otter Lutra enudris

Ocelot Felis pardalis

Jaguar Panthera onca

Bearded river turtle Podocnemis unifilis

Cayenne river turtle Podocnemis cayennensis

Spectacled caiman Caiman crocodilus

Boa constrictor Constrictor constrictor

Anaconda Eunectes murinus

Maguari stork Euxenura maguari

Jabiru Jabiru mycteria

Buff-necked ibis Cercibis oxycerca

The following species now exist only as small local populations:

Yellow-crowned night heron Nyctanassa violacea

Whispering ibis Phimosus infuscatus

Limpkin Aramus guarauna

Hoatzin Opisthocomus hoazin

The scarlet ibis Eudocimus ruber, comb duck Sarkidiornis melanotos, Muscovy duck Cairina moschata, crested eagle Morphnus guianensis, harpy eagle Harpia harpyja and ornate hawk eagle Spizaëtus ornatus, after being on the marginal list for a long time, have recovered reasonably well, and vultures are also seen in larger numbers than previously. Whistling ducks, parrots and greater cow birds have increased, and large flocks do some damage to crops. Jaguars are killed in cattle rearing areas whenever encountered, and reports of attacks on cattle are fairly frequent.

Hawks, owls and the larger macaws have never been very numerous, and they are widely distributed. Owls have adjusted well to man's presence. The larger hawks are not often seen but are by no means in danger, while the Everglade kite Rosthramus sociabilis, threatened elsewhere, is common. Recently flocks of up to a hundred blue and yellow macaws Ara ararauna have been seen.

The four species of marine turtles breeding on the Guiana shores-green, leathery, hawksbill and Pacific ridley-are still 


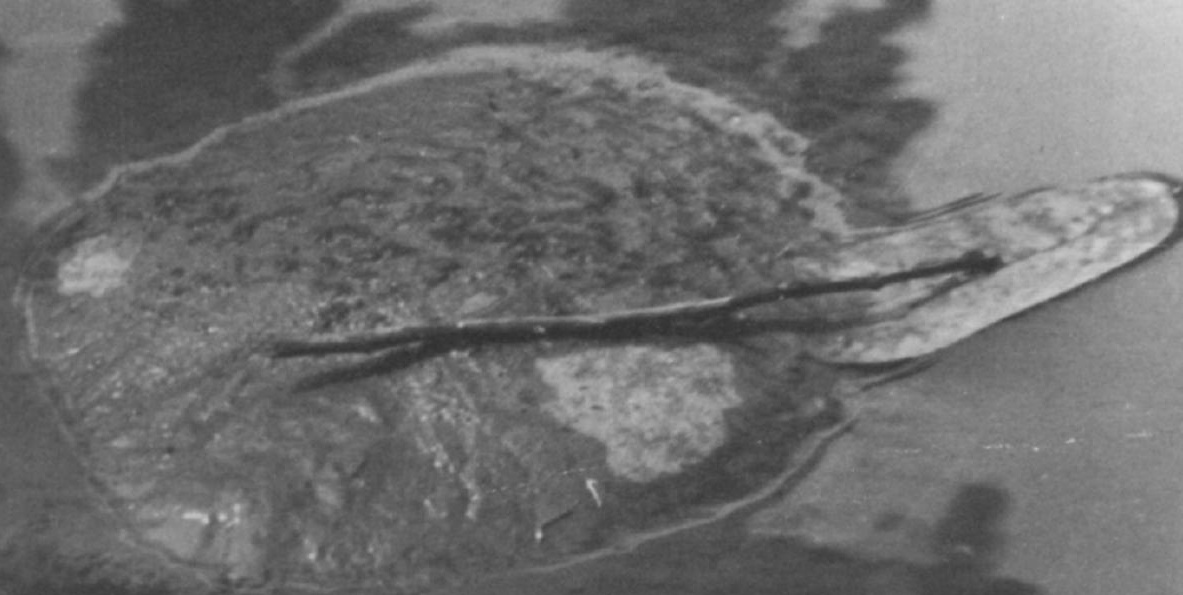

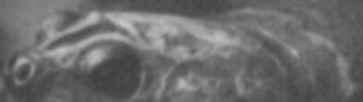

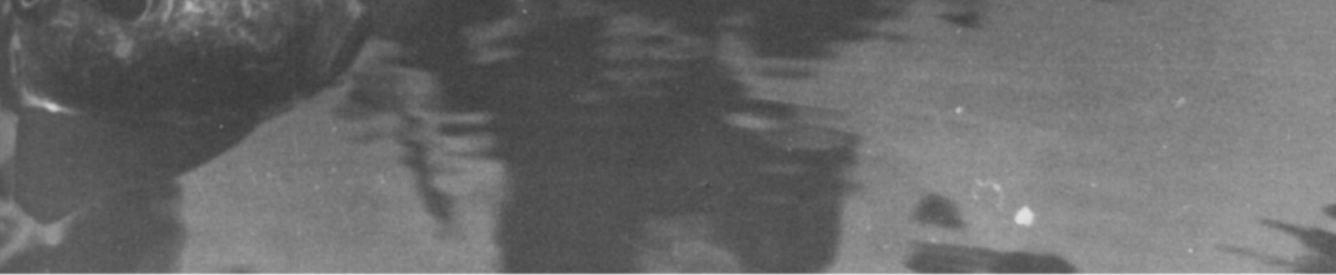

ORINOCO RIVER TURTLE above-rare and threatened

CAIMANS are still seen in remote swamps

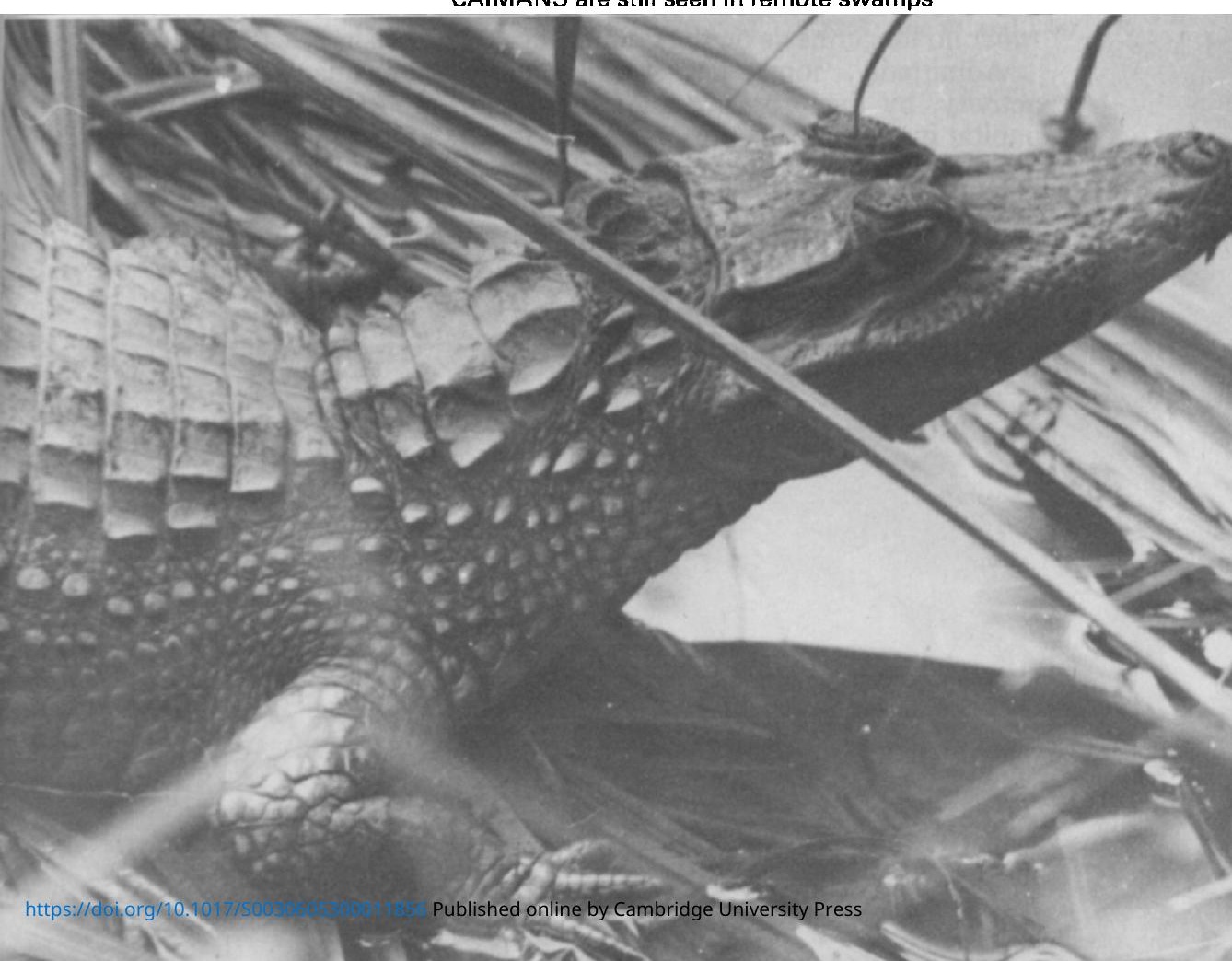




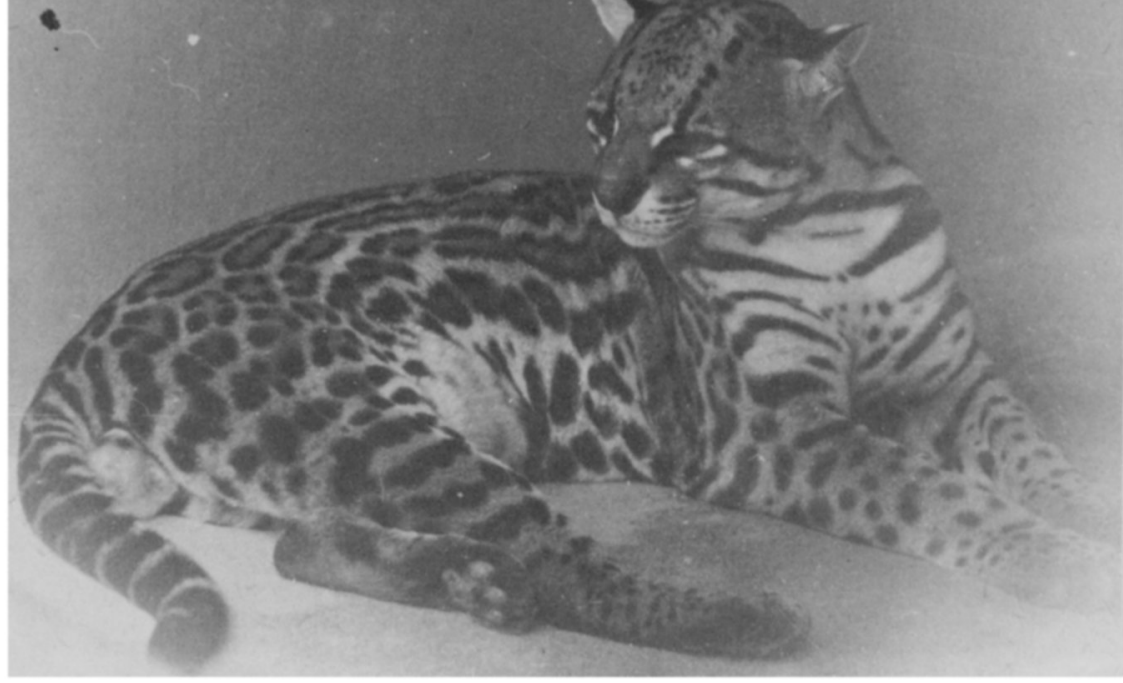

OCELOT- heavily hunted

heavily hunted, both eggs and adults being taken in large numbers, with adverse effects on world populations. In addition many nesting beaches are being eroded by the sea, thus reducing the breeding areas, and others are becoming more accessible to exploiters.

Migrant waders from the north, visiting the shores and swamps of Guiana each year on their way to their wintering grounds in the Chaco and Pampas, are heavily hunted; large numbers are netted or killed with guns and primitive divices, and the annual flocks greatly reduced. At least one species, the Eskimo curlew Numenius borealis, has been exterminated. The American flamingo Phoenicopterus ruber no longer nests on the Guiana shores, but visits occasionally.

Admittedly, some species will benefit from man's increasing activity, by the provision of more food and a greater variety of habitat in place of the present climax forests and savannas. And it is hoped that the protective measures now being introduced, but difficult to enforce, will in time give way to positive scientific management which will help to realise the economic values of wildlife and wilderness in the Guianas.

MARINE TURTLES - killed and drying in the sun 